\title{
Hypospadiasis előfordulása öt fivérben
}

\author{
Mavrogenis Stelios dr. ${ }^{1}$ - Czeizel Endre dr. ${ }^{2}$ \\ ${ }^{1}$ Országos Onkológiai Intézet, Uro-onkológiai Osztály, Budapest \\ ${ }^{2}$ „Genetikai Ártalmak Társadalmi Megelőzése” Alapítvány, Genetikai Tanácsadó, Budapest
}

\begin{abstract}
Egészséges szülőpár 5 fiában fordult elő izolált hypospadiasis ( 1 glandularis és 4 coronalis), több gyermekük nem is volt. Ilyen sokszoros családi halmozódásról még nem számoltak be európai eredetű, nem vérrokon szülők fiaiban. $\mathrm{Az}$ androgén inszenzitivitás szindróma enyhe formáját feltételezték a szerzők, ezért nemzetközi kollaborációban az elsőszülött fiúban vizsgálták az androgénreceptort kódoló gén X-kromoszómához kötött variánsát. E gén 1-8 exonjainak környező intronjainak DNS-szekvenálása nem tárt fel CAG-triplet kóros ismétlődést. A családban az izolált hypospadiasis extrém halmozódása segítheti a multifaktoriális eredetű izolált hypospadiasis hátterében álló poligénes öröklődés megismerését, ezért az amerikai egyesült államokbeli Pittsburgh genetikai intézetével együttmúködve próbálják a szerzők ezeket a génpolimorfizmusokat megismerni. Orv. Hetil., 2015, 156(33), 1348-1352.
\end{abstract}

Kulcsszavak: hypospadiasis, családi halmozódás, kóreredet, génazonosítás

\section{Isolated hypospadias in $\mathbf{5}$ brothers}

The healthy couple had five sons with hypospadias (glandular 1, coronal 4) without other child. Similar familial cluster has not reported in the sons of European parents without consanguinity. Mild form androgen insensitivity syndrome was expected in these 5 boys because of the X-linked androgen receptor gene, however, sequencing of the entire coding region (exons 1-8) and all intron-exon boundaries of the androgen receptor gene did not reveal abnormality and the CAG repeat was found in the normal range (21 repeats). This extreme familial cluster may help us to elucidate gene polymorphisms in the polygenic background of the multifactorial origin of isolated hypospadias. Therefore, the authors collaborate with a genetic institute in Pittsburg, USA to perform whole genome sequencing in these probands and their parents.

Keywords: hypospadias, familial cluster, etiology, gene identification

Mavrogenis, S., Czeizel, E. [Isolated hypospadias in 5 brothers]. Orv. Hetil., 2015, 156(33), 1348-1352.

(Beérkezett: 2015. június 6.; elfogadva: 2015. július 2.)

\section{Rövidítések}

$\mathrm{AR}=$ androgénreceptor; GAM = genital anomalies of males; IHS = izolált hypospadiasis

A fejlődési rendellenességeket szokás a gyakoriságuk alapján is osztályozni. A gyakoriak közé azok kerülnek, amelyeknek előfordulása 1000 születésre számítva legalább egy. Magyarországon ilyen 10 van, ebből 9 izolált fejlődési rendellenesség [1], míg a 10. a Down-kór. A gyakori izolált fejlődési rendellenességek egyike a hypospadiasis, amelynek a születéskori gyakorisága Magyarországon 4,31/1000 [2, 3, 4].
A terhesség 3. hónapjának a végén és a 4 . hónapjának elején alakul ki a húgycső végleges formája. A hímvessző alsó felszínén elhelyezkedő húgycsőlemez közepén, hosszanti vályúszerú bemélyedés alakul ki, majd ennek a gáttól a makk irányába történő záródása hozza létre a húgycsövet (1. ábra). Ha ezt a folyamatot vezérlő genetikai program hibás vagy a hibátlan genetikai program megvalósulását külső tényező megzavarja, a záródási folyamat nem fejeződik be és ennek következtében húgycsőhasadék alakul ki [5].

A hypospadiasis súlyosságát a hímvessző alsó felszínére kerülő húgycsőnyílás lokalizációja határozza meg (2. ábra). A hypospadiasis osztályozásakor három fó csopor- 


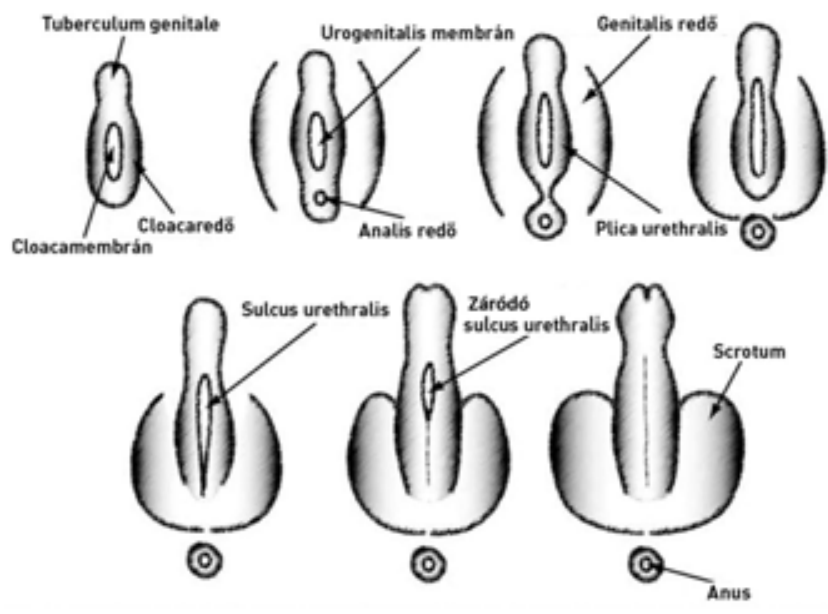

1. ábra | A húgycső záródásának folyamata

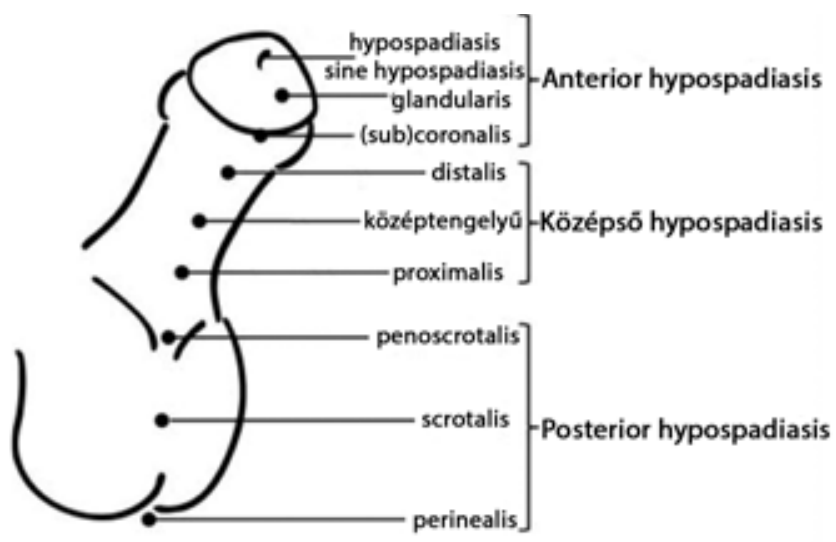

2. ábra

A hypospadiasis különböző súlyosságú fokozatai a húgycsőnyílás lokalizációja alapján

tot különítenek el és ezen belül alcsoportok/típusok ismertek [6]:

1. Enyhe súlyosságú, úgynevezett elülső (anterior) csoport:

- glandularis,

- (sub)coronalis.

2. Közepes súlyosságú, középső lokalizációjú vagy peniscsoport:

- distalis,

- középtengelyű (midshaft),

- proximalis.

3. Súlyos, úgynevezett hátsó (posterior) csoport:

- penoscrotalis,

- scrotalis,

- perinealis.

A hypospadiasisos esetek értékelésekor az első feladat az izolált és multiplex megnyilvánulású esetek elkülönítése, mivel alapvetően eltérő a kóreredetük és klinikai súlyosságuk [7].

I. Az izolált hypospadiasis eseteiben nem csak a hímvessző, illetve ezen a rendellenes húgycső érintett, mivel ezek penishypoplasiával és hasadt fitymával (preputiummal) és fitymafékkel (frenulum preputii-val) társulnak.

II. GAM- (genital anomalies of males) komplex [8], amikor a hypospadiasis rejtettheréjüséggel és inguinalis herniával együtt jelentkezik.

III. A multiplex hypospadiasis azt jelenti, hogy a hypospadiasishoz más, nem genitális eredetû rendellenességek társulnak [9]. Ennek elméletileg két csoportja lehet:

a) Olyan rendellenesség-szindrómák, amelyeknek egyik komponense a hypospadiasis, és amit mutáns gén (például Smith-Lemli-Opitz-szindróma) vagy kromoszómaaberráció (például tetrasomy 18p) [10], esetleg teratogén ártalom (az antiepileptikum valproát [11]) okozhat.

b) Random kombináció, amikor a hypospadiasishoz más rendellenesség (például ajakhasadék) társul, anélkül, hogy ez valamelyik rendellenesség-szindróma része lehetne.

A gondot az jelenti, hogy a szindrómás eseteket gyakorta nem ismerik fel, és akkor ezek is a random kombinációk közé sorolódnak be, ezért szokás nem azonosított multiplex rendellenességekről beszélni [9].

Míg a hypospadiasis-szindrómák általában genetikai vagy teratogén ártalmak következményei, addig az izolált esetek kóreredete a multifaktoriális modellnek felel meg $[1,12,13,14]$, vagyis a genetikai hajlamért felelős poligénrendszert ártalmas külső hatások provokálhatják, vagy éppen védőhatások elnyomhatják [7].

A továbbiakban csak az izolált hypospadiasis- (IHS-) esetekkel foglalkozunk. A korábbi magyar genetikai családvizsgálat szerint az IHS-esetek első fokú rokonaiban az IHS elöfordulása sokszorosa a szokásos gyakoriságnak. Így az édesapák 3,7\%-ának volt ilyen IHS-e, és 4,8\%-ánál találtak a fivéreikben ismételt IHS-előfordulást $[1,12]$. Ráadásul a súlyosabb penistípusban nagyobb volt a családi halmozódás mértéke, mint az enyhébb coronalis típusban. Mindezek az adatok igazolták az IHS multifaktoriális eredetét, és az örökletesség (úgynevezett heritabilitás) mértéke $0,65 \pm 0,18$ volt. Más országokban végzett vizsgálatok hasonló eredménnyel zárultak [13, 14]. A multifaktoriálisküszöb-modell értelmében az IHS-esetek nem IHS-ben szenvedő első fokú rokonainak úgynevezett kvantitatív jellegeiben a küszöbhöz fokozott közelség észlelhető. Ezt magyar kutatóknak sikerült elsőként igazolni az IHS-esetek szüleinek csökkent fertilitása [15] és az apák kóros ondósejt-termelődése alapján [16].

Az IHS-esetek multifaktoriális kóreredete alapján döntő többségük sporadikusan jelentkezik. Éppen ezért az ettől eltérő különleges eseteket publikálták. Egy apában és két fiában előforduló IHS alapján feltételezték az autoszóm domináns öröklődést [17]. Egy beduin család 8 férfi tagjának volt IHS-e [18], és Izraelben egy muszlim család 4 fivérében találtak IHS-t [19], egészséges, tehát nem IHS-ben szenvedő, de vérrokon szülők gyermekeiben. Tudomásunk szerint azonban európai erede- 


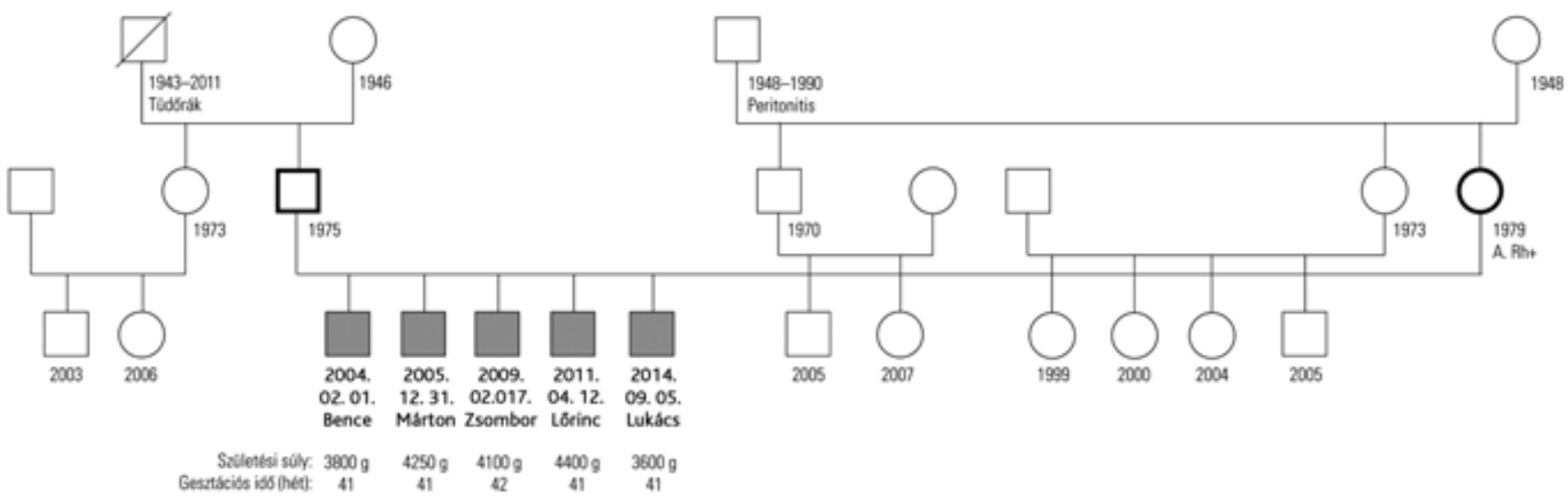

3. ábra

| Az 5 fivér családfája

tû, nem vérrokon, egészséges házaspár mind az 5 fiában még soha nem észleltek IHS-t, éppen ezért ezt a családot bemutatásra érdemesnek tartjuk.

\section{Esetismertetés}

A család 2012. október 8-án kereste fel alapítványunk genetikai tanácsadóját. Az egészséges szülőpárnak 4 fia született, és mindegyiknek IHS-e volt. A bemutatott családfán adataik megtalálhatók (3. ábra), és az is, hogy nálunk történt jelentkezésük után még egy terhességre vállalkoztak. A 2014-ben megszületett fiúnak ugyancsak IHS-e volt. A proband fiúk rendellenességének és nemi szervének vizsgálatát urológus, e közlemény első szerzője végezte. A fiúknak, a másodszülöttől eltekintve, coronalis típusú IHS-e volt, az első és harmadik fiúnál már elvégezték a korrekciós mútétet, míg a két legkisebb erre csak elő van jegyezve bizonyos életkor elérésekor. A másodszülött fiúnak glandularis IHS-e volt, a szülők szerint nála csak cirkumcízió történt. A fiúk két heréje normális nagyságú volt a herezacskóban.

A szülők egészségesek voltak, egymással rokonságban nem álltak. Fertilitásuk jónak mondható, mivel a tervezett fogamzásokat 1-3 hónap alatt elérték. Az anya menarchéja 13 éves korában jelentkezett, és azóta szabályos a mensesciklusa (6-7/32 nap). A házasság előtt és után 4 évig fogamzásgátló tablettát szedett. Az apa nemi szerve elváltozást nem mutatott jó spermatogrammal (92 millió/ml, mozgás $80 \%$ és kóros alak 25\%).

A szülők 5 fia jó születési súllyal a 41-42. gesztácios héten jött a világra.

A szülőkkel való konzultáció után belga laboratóriummal (GENDIA-Genetic Diagnostic Network, Antwerpen) együttmúködésben az érintett legidősebb fiú AR- (androgénreceptor-) génjének DNS-analízisét végeztettük el. Ennek során az AR-gén teljes kódolórégiójában (exons 1-8) és az összes intron-exon körítésben (boundaries) leolvasták a DNS nukleotidjait. Az AR gén referenciaszekvenciája az EU Genbank NM-000044.2 számú mintája volt 'A'-val kezdve az ATG „start codon at position 1 ".

Az AR-gén teljes kódolórégiója (exons 1-8) és az öszszes intron-exon boundaries nem mutatott DNS-eltérést: 1. A CAG-ismétlődés normális tartományban volt a maga 21 ismétlődésével. 2. Az AR-gén úgynevezett benignus variációja sem volt észlelhető. Eszerint a legidősebb fiú IHS-eredetében az AR-gén mutációja nem játszott szerepet.

\section{Megbeszélés}

Az IHS-nek, mint utaltunk rá, különböző súlyosságú megnyilvánulásai vannak. Magyarországon két vizsgálat alapján ismerjük ezek eloszlását (1. táblázat). Az IHSesetek súlyossági csoportjait és ezen belül a típusokat általában nem jelezték a Veleszületett Rendellenességek Országos Nyilvántartásának (VRONY) küldött nyomtatványon. Ezeket ezért csak 1980 és 1996 között lehetett részlegesen értékelni, mivel a VRONY keretén belül a szülők kérésére - 10 rendellenesség-csoportban szülői értekezletet szerveztek, ahová az előző évben bejelentett gyermekeket szüleikkel együtt meghívták [20, 21]. Az

\begin{tabular}{|c|c|c|c|c|}
\hline 1. táblázat & \multicolumn{4}{|c|}{$\begin{array}{l}\text { Az értékelhető IHS-esetek típus szerinti eloszlása két magyar } \\
\text { vizsgálatban, a Veleszületett Rendellenességek Országos Nyil- } \\
\text { vántartása (VRONTY, 1980-1996) és egy, a gyermekek szemé- } \\
\text { lyes vizsgálatára alapozott genetikai-epidemiológiai vizsgálatban }\end{array}$} \\
\hline \multirow[t]{2}{*}{ IHS típusa } & \multicolumn{2}{|c|}{ VRONY, 1980-1996 } & \multicolumn{2}{|c|}{ Epidemiológiai minta } \\
\hline & No. & $\%$ & No. & $\%$ \\
\hline Glandularis & 372 & 23,5 & 32 & 10,9 \\
\hline Coronalis & 658 & 41,6 & 117 & 39,8 \\
\hline $\begin{array}{l}\text { Penis } \\
\text { (összevonva) }\end{array}$ & 490 & 31,0 & 134 & 45,6 \\
\hline Penoscrotalis & 41 & 2,6 & 8 & 2,7 \\
\hline Scrotalis & 11 & 0,7 & 2 & 0,7 \\
\hline Perineoscrotalis & 8 & 0,5 & 1 & 0,3 \\
\hline Összesen & 1580 & 100,0 & 294 & 100,0 \\
\hline
\end{tabular}


egyik ilyen az IHS volt. Itt meghívott szakértők megvizsgálták a gyermekeket is, így az IHS csoportja és típusa tisztázható volt. Másfelől egy korábbi személyes vizsgálatra alapozott genetikai epidemiológiai vizsgálatban 294 IHS-fiút értékeltek [1, 12]. A két vizsgálat között lényegében csak a minor anomáliának számító glandularis típus ritkább és a penistípus gyakoribb részesedése tért el. Az ismertetésre kerülő 5 fiú közül 4 az IHS coronalis típusába tartozott.

Az IHS-esetek általában valamivel rövidebb gesztációs idő (39,2 vs. 39,4 hét) után számottevően kisebb súllyal (3127 vs. 3323 g) jönnek a világra, ezért a kis súlyúak aránya náluk jóval gyakoribb (13,0\% vs. 5,0\%) [22]. Hasonló eredményre jutottak más vizsgálatokban is [23]. Mindezek azonban nem voltak jellemzőek az értékelt fiúkra. Ahogy a rosszabb szociális helyzet sem [24], mindkét szülő értelmiségi foglalkozású és jómódban élnek [25].

Az IHS-magzatot világra hozó várandósokban gyakoribb a praeeclampsia és ritkább a kezelésre szoruló émelygés, hányás, hányinger [25]. Az utóbbi gyakorta fokozott rendellenesség-kockázattal társul [26]. A probandok édesanyja ilyen jellegű terhességi komplikációkról nem számolt be. Az anyai betegségek közül az epilepszia jelent magasabb kockázatot az IHS-re [27], az édesanyának ilyen betegsége nem volt. A gyógyszerek közül elsősorban a női nemi hormonok szedését követő magasabb IHS-kockázatról számoltak be [28, 29, 30, 31, 32], és ezt a mi vizsgálatunk is megerősítette [27]. A probandok édesanyja azonban ilyen kezelésben nem részesült.

A probandok apjának a fertilitása rendben volt.

Az IHS-fivérek ilyen mérvű halmozódásáról eddig még nem számoltak be európai eredetü nem vérrokon szülőkben. A családfaadatok alapján autoszóm recesszív öröklődésre gondolhatunk, ami egészséges szülők gyermekében szokott ismételten előfordulni - mégpedig Mendel II. szabályának megfelelően 25\%-os kockázattal. Ebben a családban azonban 100\%-os kockázatról van szó.

Egy kutatásban 40 IHS-eset hímvesszőszövetének DNS-analízisére vállalkoztak és egy penis „midshaft” típusú páciensben az AR-gén (pro546 to ser) 2 exonjában a nukleotidákban C-to-T változást (transition) észleltek [33]. Ennek alapján feltételezték, hogy az IHS hátterében az „androgén érzéketlenség szindróma” állhat, amely az AR-gén mutációjára vezethető vissza, és ezt két vizsgálat meg is erősítette $[34,35]$. Az AR-gén az X nemi kromoszóma rövid karjának 12-es régiójában van, és az IHS-esetekben a poliglutamin- (CAG-) ismétlődés megsokszorozódott, ezért az úgynevezett $\mathrm{N}$-terminusban csökkent az AR-gén transzaktivációs funkciója [36]. Két másik vizsgálatban a hosszabb CGN-ismétlődést találták sokszorosnak a penistípusú IHS-esetekben, és náluk a CAG-ismétlődés nem öltött kóros mértéket [37, 38]. E család elsőszülött fiában ilyen genetikai elváltozás azonban nem igazolódott.
Újabban az IHS-ért felelős sokgénes rendszeren belül számos gént azonosítottak (WT1, SF1, BMP4, BMP7, HOXA4, HOXB6, FGF8, FGFR2, AR, HSD3B2, SRD5A2, ATF3, MAMLD1, MID1, BNC2) [6], de ezek csak néhány IHS-esetben fordultak elő, tehát minden IHS-esetben előforduló génmutációt nem találtak. Van der Zanden és mtsai [39] szerint DGKK (diacylglycerol kinase kappa) gén mutációja igazolható IHS-es esetekben leggyakrabban, és ez a gén az X nemi kromoszóma rövid karjának 11-22 régiójában van.

Eddig tehát nem találtunk konkrét genetikai magyarázatot e nagyon szokatlan, 5 fivérben előforduló IHS családi halmozódására. Szerencsénkre e különös eset több génlaboratórium érdeklődését felkeltette, ezért tudományos együttmúködés keretében a szülők és az 5 fiú DNSmintáját kiküldtük az Amerikai Egyesült Államokba, mivel Pittsburghban, az egyetem keretében múködő molekuláris genetikai laboratórium, személy szerint $D r$. Alexander Yatsenko vállalta teljes DNS-molekulájuk szekvenálását. A kiküldött DNS-minták vizsgálati eredménye Yatsenko szerint nagyon különös DNS-polimorfizmusra utal, ezért 50 egészséges, nem IHS-es és 50 sporadikus IHS-esettel akarja összehasonlítani ezt a DNS-mintázatot, hogy a lehetséges genetikai kapcsolatot igazolja. Ez a munka azonban hosszú időt vesz igénybe.

Etikai hozzájárulás: Az AR-gén vizsgálatához és a teljes genom szekvenálásához a szülők írásos engedélyt adtak, és az ehhez szükséges vérmintákat biztosították.

Anyagi támogatás: Az elsőszülött proband AR-gén vizsgálatának a költségét $M$. S. fedezte, a család minden tagjának DNS-analízisének költségét, beleértve a minták kiküldését is, a Pittsburghi Egyetem vállalta.

Szerzôi munkamegosztás: M. S.: A probandok vizsgálata, a kézirat megírása. C. E.: Genetikai tanácsadás, a kézirat megírása. A cikk végleges változatát mindkét szerző elolvasta és jóváhagyta.

Érdekeltségek: A szerzőknek nincsenek érdekeltségeik.

\section{Irodalom}

[1] Czeizel, A. E., Tusnády, G.: Aetiological studies of isolated common congenital abnormalities in Hungary. Akadémiai Kiadó, Budapest, 1984.

[2] Pazonyi, I., Czeizel, A. E., Ludányi I., et al.: Frequency and significance of minor anomalies. [A minor rendellenességek gyakorisága és jelentôsége.] Orv. Hetil., 1975, 116(1), 3-8. [Hungarian]

[3] Czeizel, A. E.: Epidemiological studies of congenital abnormalities in Hungary. Issues Rev. Teratol., 1993, 6(3), 85-124.

[4] Mavrogenis, S., Czeizel, A. E.: Trends in the prevalence of recorded isolated hypospadias in Hungarian newborn infants during the last 50 years - A population-based study. Reprod. Toxicol., 2013, 42, 251-255. 
[5] Virtanen, H. E., Toppari, J.: Epidemiology and pathogenesis of cryptorchidism. Hum. Reprod. Update, 2008, 14(1), 49-58.

[6] Van der Zanden, L. F., van Rooij, I. A., Feitz, W. F., et al.: Aetiology of hypospadias: a systematic review of genes and environment. Hum. Reprod. Update, 2012, 18(3), 260-283.

[7] Czeizel, A. E.: The estimation of human teratogenic/fetotoxic risk of exposures to drugs on the basis of Hungarian experiences: a critical evaluation of clinical and epidemiological models of human teratology. Expert Opin. Drug Saf., 2009, 8(3), 283-303.

[8] Czeizel, A. E.: Genital anomalies of males: GAM-complex. Eur. J. Pediatr., 1987, 146(2), 181-183.

[9] Czeizel, A. E., Telegdy, L., Tusnády, G.: Multiple congenital abnormalities. Akadémiai Kiadó, Budapest, 1988.

[10] Côté, G. B., Petmezaki, S., Bastakis, N.: A gene for hypospadias in a child with presumed tetrasomy $18 \mathrm{p}$. Am. J. Med. Genet., 1979, 4(2), 141-146.

[11] Rodríguez-Pinilla, E., Mejías, C., Prieto-Merino, D., et al.: Risk of hypospadias in newborn infants exposed to valproic acid during the first trimester of pregnancy: a case-control study in Spain. Drug Saf., 2008, 31(6), 537-543.

[12] Czeizel, A. E., Tóth, J., Erödi, É.: Aetiological studies of hypospadias in Hungary. Hum. Hered., 1979, 29(3), 166-171.

[13] Fredell, L., Iselius, L., Collins, A., et al.: Complex segregation analysis of hypospadias. Hum. Genet., 2002, 111(3), 231-234.

[14] Schnack, T. H., Zdravkovic, S., Myrup, C., et al.: Familial aggregation of hypospadias: a cohort study. Am. J. Epidemiol., 2008, 167(3), 251-256.

[15] Czeizel, A. E., Tóth, J.: A correlation between the birth preva lence of isolated hypospadias and parental subfertility. Teratology, 1990, 41(2), 167-172.

[16] Fritz, G., Czeizel, A. E.: Abnormal sperm morphology and function in fathers of hypospadiacs. J. Reprod. Fertil., 1996, 106(1), 63-66.

[17] Lowry, R. B., Kliman, M. R.: Hypospadias in successive generations - possible dominant gene inheritance. Clin. Genet., 1976 9(3), 285-288.

[18] Frydman, M., Greiber, C., Cohen, H. A.: Uncomplicated familial hypospadias: evidence for autosomal recessive inheritance. Am. J. Med. Genet., 1985, 21(1), 51-60.

[19] Tsur, M., Linder, N., Cappis, S.: Hypospadias in a consanguineous family. Am. J. Med. Genet., 1987, 27(2), 487-489.

[20] Czeizel, A. E.: First 25 years of the Hungarian Congenital Abnormality Registry. Teratology, 1997, 55(5), 299-305.

[21] Czeizel, A. E., Métneki, J., Béres, J.: 50 years of the Hungarian Congenital Abnormality Registry. Congenit. Anom. (Kyoto), 2014, 54(1), 22-29.

[22] Mavrogenis, S., Urban, R., Czeizel, A. E., et al.: Possible preventive effect of high doses of folic acid for isolated hypospadias: a national population-based case-control study. Am. J. Med. Genet. Part A, 2014, 164A(12), 3108-3114.

[23] Hussain, N., Chaghtai, A., Herndon, A., et al.: Hypospadias and early gestational growth restriction in infants. Pediatrics, 2002, $109(3), 473-478$

[24] Carmichael, S. L., Shaw, G. M., Lammer, E. J.: Environmental and genetic contributors to hypospadias: a review of the epidemiological evidence. Birth Defects Res. Part A Clin. Mol. Teratol., 2012, 94(7), 499-510.
[25] Mavrogenis, S., Urban, R., Czeizel, A. E., et al.: Pregnancy complications in the mothers who delivered boys with isolated hypospadias - a population-based case-control study. J. Matern. Fetal Neonatal Med., 2015, 28(4), 489-493.

[26] Czeizel, A. E., Puhó, E., Ács, N., et al.: Inverse association between severe nausea and vomiting in pregnancy and some congenital abnormalities. Am. J. Med. Genet. Part A, 2006, $140 A(5), 453-462$.

[27] Mavrogenis, S., Urban, R., Czeizel, A. E., et al.: Maternal risk factors in the origin of isolated hypospadias: A population-based case-control study. Congenit. Anom. (Kyoto), 2014, 54(2), 110-115.

[28] Aarskog, D.: Maternal progestins as a possible cause of hypospadias. N. Engl. J. Med., 1979, 300(2), 75-78.

[29] Resseguie, L. J., Hick, J. F., Bruen, J. A., et al.: Congenital malformations among offspring exposed in utero to progestins, Olmsted County, Minnesota, 1936-1974. Fertil. Steril., 1985, 43(4), 514-519.

[30] Check, J. H., Rankin, A., Teichman, M.: The risk of fetal anomalies as a result of progesterone therapy during pregnancy. Fertil. Steril., 1986, 45(4), 575-577.

[31] Scially, A. R.: Developmental effects of progesterone and its derivatives. Reprod. Toxicol., 1988, 2(1), 3-11.

[32] Kim, K. S., Torres, C. R. Jr., Yucel, S., et al.: Induction of hypospadias in a murine model by maternal exposure to synthetic estrogens. Environ. Res., 2004, 94(3), 267-275.

[33] Sutherland, R. W., Wiener, J. S., Hicks, J. P., et al.: Androgen receptor gene mutations are rarely associated with isolated penile hypospadias. J. Urol., 1996, 156(2), 828-831.

[34] Hiort, O., Klauber, G., Cendron, M., et al.: Molecular characterization of the androgen receptor gene in boys with hypospadias. Eur. J. Pediatr., 1994, 153(5), 317-321.

[35] Alléra, A., Herbst, M. A., Griffin, J. E., et al.: Mutations of the androgen receptor coding sequence are infrequent in patients with isolated hypospadias. J. Clin. Endocrinol. Metab., 1995, $80(9), 2697-2699$

[36] Chamberlain, N. L., Driver, E. D., Miesfeld, R. L.: The length and location of CAG trinucleotide repeats in the androgen receptor $\mathrm{N}$-terminal domain affect transactivation function. Nucleic Acids Res., 1994, 22(15), 3181-3186.

[37] Aschim, E. L., Nordenskjöld, A., Giwercman, A., et al.: Linkage between cryptorchidism, hypospadias, and GGN repeat length in the androgen receptor gene. J. Clin. Endocrinol. Metab., 2004, $89(10), 5105-5109$.

[38] Radpour, R., Rezaee, M., Tavasoly, A., et al.: Association of long polyglycine tracts (GGN repeats) in exon 1 of the androgen receptor gene with cryptorchidism and penile hypospadias in Iranian patients. J. Androl., 2007, 28(1), 164-169.

[39] Van der Zanden, L. F., van Rooij, I. A., Feitz, W. F., et al.: Common variants in DGKK are strongly associated with risk of hypospadias. Nat. Genet., 2011, 43(1), 48-50.

(Czeizel Endre dr., Budapest, Törökvész lejtő 32., 1026 e-mail: czeizel@interware.hu) 